\title{
Editorial
}

\section{Mudanças Editoriais na Rbem}

\author{
Editorial Changes to Rbem
}

Sergio Rego I

O ano de 2013 traz importantes mudanças para a Revista Brasileira de Educação Médica. Após conquistas tão importantes como a integração na coleção do Scielo, nossa Revista tornará obrigatória a publicação online também da versão no idioma inglês de todos os artigos aqui publicados. Dessa forma, ofereceremos aos nossos autores o acesso, via internet, aos estudiosos internacionais do tema, ampliando o impacto dos trabalhos aqui publicados. Estamos incluindo nas normas para submissão de trabalhos a obrigatoriedade de que seja providenciada a versão inglesa do artigo, assegurando também a publicação na versão em português. Embora reconheçamos que atualmente o idioma científico internacional é o inglês, entendemos que nossa Revista tem um objetivo político também: ser o veículo de disseminação de teorias e experiências que proporcionem o aprimoramento da formação profissional na área de saúde em nosso país. Daí que a publicação do trabalho em português também será obrigatória. Lamentavelmente, todavia, a Abem não terá como arcar com os custos de versão e de revisão ortográfica e gramatical da versão em língua inglesa, razão pela qual seremos obrigados a transferir os custos adicionais de publicação aos autores, a exemplo do que já é feito por tantas revistas, nacionais e internacionais. Ofereceremos duas alternativas aos autores: indicaremos alguns tradutores cuja adequação é por nós reconhecida ou realizaremos a revisão da versão na língua inglesa com um de nossos especialistas. Em ambos os casos, o custo será transferido para os autores.

Nossa Revista insere-se, no Scielo, na área de Educação, mas é também pertinente à área da Saúde Coletiva, inserida na grande área de recursos humanos em saúde. Embora não desejemos perder nossa identidade como a única publicação brasileira especializada em educação médica, entendemos, junto com a Abem, que a discussão sobre formação de profissionais de saúde não se esgota na discussão da formação médica propriamente dita e que as colaborações de estudiosos e pesquisadores da educação de outros profissionais que não médicos são também de nosso interesse, assim como nossas reflexões sobre a formação médica são de interesse deles. Tivemos, no passado recente, uma experiência extraordinária com a publicação dos suplementos dedicados ao PET-Saúde e ao Pró-Saúde, nos quais as abordagens multiprofissionais foram a tônica. Queremos estender esta experiência aos números regulares da Revista a fim de intensificar o intercâmbio de experiências e reflexões, e contribuir para aumentar o impacto dos artigos e da própria Revista na comunidade acadêmica nacional e internacional. Para isto, contaremos com um editor associado específico para este trabalho, buscando maximizar os resultados desta nova abordagem. Procuraremos incluir em cada edição até 30\% de artigos com esta perspectiva.

Por fim, embora não menos importante, existe a questão da autoria dos artigos. As normas adotadas pela Revista há mais de uma década são as preconizadas pelo International 
Committee of Medical Journal Editors, também conhecidas como normas de Vancouver. Reconhecemos como autor de um trabalho apenas e tão somente aquele que satisfaça as seguintes condições: (1) ter dado contribuições substanciais para a concepção e desenho do estudo, aquisição de dados ou análise e interpretação de dados; (2) ter participado da elaboração de versão inicial do artigo ou de sua revisão crítica para conteúdo intelectual significativo; (3) ter aprovado a versão final encaminhada para publicação. Participar da coleta de dados, realizar a revisão bibliográfica, codificar ou digitar resultados não constituem, isoladamente, requisitos suficientes para se dar crédito de autoria a uma pessoa, ainda que participante do grupo de pesquisa. Assim, dado o tipo de estudos e pesquisas habitualmente submetido à Revista e com o objetivo específico de valorizar a autoria de trabalhos científicos, combatendo a autoria de presente ou honorífica, a Revista passa a adotar o critério de admitir no máximo quatro autores por artigo. Em casos excepcionais que ultrapassem este limite, os autores deverão fornecer aos editores uma detalhada explanação sobre o processo de autoria do artigo. 